\title{
The Death and Life of the Devil's Son: A Literary Analysis of a Neglected Tradition
}

\author{
Zohar Hadromi-Allouche \\ University of Aberdeen \\ ha-zohar@hotmail.com
}

\section{Introduction}

What is the origin of evil? An answer to this perennial question is offered by an Islamic myth, which has existed in the collective memory of Muslim Mediterranean society for over a thousand years. As this myth has been re-told over the years, its emphases varied according to the contexts in which it is being narrated. These contexts extend from (at least) the 4th A.H./1oth C.E. century to the present day, and from theological arguments to natural disasters and geo-political circumstances.

The earliest source in which I have been able to locate this story is Nawādir al-Ușūl fi Ma'rifat Ahâàith al-Rasūl, by the mystic al-Hakìm al-Tirmidhī (d. 320 A.H./932 C.E.). Al-Hakīm al-Tirmidhī relates this report on the authority of Wahb b. Munabbih (d. 110-116 A.H.): ${ }^{1}$

Iblīs gave a son of his [ibn (an) lahu] to Eve, and said: "Look after him [Ukfulīhi]."

${ }^{1}$ Wahb b. Munabbih b. Kāmil b. Sayh b. dhī Kunnāz al-Yamanī al-Ṣan‘ānī al-Dhamarī, Abū 'Abdāllah al-Abnawī. Yemenite narrator of Persian origin and author-transmitter from South Arabia. Wahb was considered a great authority of Biblical traditions, although it seems that he was probably born a Muslim. Served as a judge in Șan'ầ, but at a certain stage he was imprisoned, due to his belief in free will (Qadar; see also below, note 11) and/or because of his contacts with Ahl al-Kitāb. Ibn Hajar, Tahdhīb al-Tahdhīb, Vol. 11, p. 147; R.G. Khoury, "Wahb b. Munabbih," $E I^{2}$, Vol. XI, pp. 34-36. Cf. Alfred-Louis de Prémare, "Wahb b. Munabbih, une figure singulière du premier islam", Annales: Histoire Sciences Sociales, mai-juin 2005. 
When Adam came he asked: "What is this, oh Eve?"

She said: "Our enemy ['aduwunā] Iblīs brought it, and told me 'Look after him'." Said [Adam]: "Haven't I told you not to obey him in anything? He is the one who deceived us [gharranā] so that we fell into disobedience / sin [ma șiya]."

He turned to the child [ila al-walad], cut him into four, and hung each quarter on a tree, out of anger with him [with Iblīs]. Then came Iblīs and said "Oh Eve, where is my son?", and she informed him of what Adam had done. [Iblīs] then said "Oh Khannās" and [the child] lived [fa-hayiya $]$ and answered him.

[Once more Iblīs] brought him to Eve and told her: "Look after him". Adam came, and burnt him in fire, and spread his ashes in the sea. Iblīs, curse be upon him ['alayhi al-la'na], came and said: "Oh Eve, where is my son?" She informed him of Adam's deeds, and he went to the sea and said: "Oh Khannās." And [the child] lived and answered him.

[Iblīs then] brought him to Eve for the third time, and said: "Look after him". Adam watched him [the child; nazara ilayhi] and slaughtered [the child; dhabahahu] and roasted him, and both [Adam and Eve] ate [the child] entirely [jami $\left.{ }^{-(a n)}\right]$. Iblis came and asked her, and Eve told him [of what had happened]. He then said: "Oh Khannās" and [the child] lived and answered him, and his voice came to him from the body of Adam and Eve. Iblīs said: "This is just what I had wanted. This is your abode, in the breast [șadr] of the child of Adam [walad Adam]" He devours (multaqim) the heart of [each] son of man [ibn Adam]; as long as [the man] is neglectful [ghäfil(an)], [Khannās] seduces [him; yuwaswisu], and when [the man] remembers Allah, [Khannās] emits his [the man's] heart and withdraws [inkhanasa]. ${ }^{2}$

This text can be interpreted on a number of levels. Here it is examined as a Hadith report, in the context of the Islamic tradition; as a folk narrative; and in comparison with three other religious stories: the expulsion from Paradise (with which it shares its characters); the sacrifice of Isaac; and that of Jesus (the father and son motif). Each of these three different levels of interpretation reveals other aspects of the story and of its multiple meanings. By presenting these separate levels side by side, and applying to them tools from the disciplines of Hadith, literature, folklore and psychology, further meanings of the text are revealed. Of a special interest is the way in

2 Al-Ḥakīm al-Tirmidhī, Nawādir al-Ușūl, Vol. 4, p. 31. 
which the analysis of the text as a folk tale contributes to the understanding of this narrative as a religious story, both in its specific context in Islam and in relation to other religious traditions.

Other matters that will be discussed below have to do with (1) the functions of the text in each of the contexts in which it exists; (2) its origin; and (3) the differences between religious and folk literature, with regard to the circulation of this story.

\section{The Text as a Hadīth Report}

\section{Circulation}

In terms of circulation, this report is unusually rare. I have been able to locate it in only two, non-authoritative sources of scholarly Hadith literature. Al-Hakīm al-Tirmidhī, who was among the most important early Ṣufi writers, wrote many books about jurisprudence, Hadīth and Șūfism, of which Nawādir al-Ușūl is one of the best-known. The book is divided into chapters-Usūl ("sources"), which deal with a variety of topics. ${ }^{3}$ The above text appears in assl 259 , which is entitled "The dispelling of the Devil's insinuations" (al-daf' min al-waswasa).

The report from al-Hakīm al-Tirmidhī's Nawādir al-Ușūl is quoted by Qurțubī (d. 671 A.H./1273 C.E.) in his Tafsìr, where the story is located in the exegesis to sūra $114(a l-N \bar{a} s){ }^{4}$

The Qurțubi version changes the beginning of the story so as to make it suit better the exegetical context: "It is said that al-Waswās al-Khannās is a son of Iblīs, whom he brought to Eve and gave him to her and said: 'Look after him'". Then the two versions are identical. ${ }^{5}$

Qurțubi remarks that he doubts the reliability of this report. Such a comment might explain the rarity of this report in the Hadith literature: ${ }^{6}$ So far, I have found no references to the story in other Hadith sources. Yet the

3 B. Radtke, John O'Kane. The Concept of Sainthood in Early Islamic Mysticism: Two Works by al-Hakim al-Tirmidhī. Richmond, U.K.: Curzon Press, 1996, p. 3.

4 Qurțubī, Tafsĭr, Vol. 2o, pp. 261-262.

5 Except for a minor difference in line 7 of the Nawädir text, where instead of "fa-akhbarathu bi-fi'l Ādam bihi" in the Nawādir, Qurțubì uses the phrase "fa-akhbarathu bi-fi'l Ādam iyāhu".

6 Ibid., p. 262. 
question remains what made Qurțubī consider this report unreliable. This question will be discussed below.

Despite its rarity in the Hadith, the story has gained popularity as a folk tale, as is evident from its inclusion in three anthologies of folk tales. Whereas two of these anthologies contain popular Palestinian stories, ${ }^{7}$ the third one contains Jewish-Yemenite folk tales. ${ }^{8}$ The story is also quoted by Nimr Sirhan in his study of Palestinian folk tales. It should be noted that whereas the scholarly Hadith sources which contain this story, date from the tenth and thirteenth centuries C.E., all folk versions of the tale located until today were collected during the twentieth century C.E. All the versions of the folk tales have been collected in an Arabic-speaking environment, which might indicate that the origin of the story is Arab or Muslim, although this is difficult to assert on the basis of the existing information. Also supporting this view, however, is the fact that the story is hardly known in Jewish and Christian religious sources. Although this story connotes with the view of some early commentators of the Bible that Cain was the son of Eve and Satan, ${ }^{9}$ the Cain story is quite different from the story discussed here. The question of the story's origin however, remains open, with a certain likelihood that the source might be Arab and/ or Muslim.

\section{Isnād}

Al-Ḥakim al-Tirmidhì does not give the whole isnād for this report. Only the name of the first transmitter is given: Wahb b. Munabbih (d. 110-116 A.H.). Considered as a transmitter of Isrä ìliy $\bar{a} t,^{10}$ and suspected of relations with

7 E.J.Hanauer, Folklore of the Holy Lands, p. 12; quoted by Nimr Sirhan, Al-Hikāya al-Sha biyya al-Falastīnīyya, p. 108. This story also appears in Ashhab, Kān Yā Mā Kān, pp. 188-189. This anthology has been translated to English: Rushdi al-Ashhab, Popular Stories from Palestine, Jerusalem: The Arab Studies Society, 1987. The story is also available from This Week in Palestine-Story of the Week [online]. Jerusalem Media \& Communication Centre (JMCC), February 2000, [cited November o6 2010], <http://thisweekinpalestine.com/details.php?id=703\&ed=63\&edid=63>.

8 IFA (Haifa), text 1141, "How did the Devil enter the human heart," collected by Heda Jason from Yehuda Jefet Schwili (Yemen), Holon [Israel], Blokonim 227, on June $5^{\text {th }}$ 1959. A German translation of this story appears in Schwili, pp. 158-159, Nr. 62.

9 Pirkey de-Rabbī Elicezer- "Horev," chapter 21 4-5; Zohar, Vol. 1, p. 28b; Kugel, The Bible As it Was, pp. 86-87; Urbach, Sages, p. 147.

10 The term Isrä'iliyyāt relates to narratives which inform of biblical personages (mainly the prophets); or edifying texts of the "time of the ancient Israelites 
the Qadariyya, ${ }^{11}$ Wahb is not very popular with the authoritative compilers. His reputation could also have led to the lack of popularity of the report in scholarly literature. However, it might also be that an unreliable transmitter was attached to the report as a reflection (or even a reinforcement) of its unpopularity. This isnād also suggests the possibility of finding parallels to this report in Jewish or Christian sources. However, as I have mentioned above, such a parallel has not been located yet.

\section{Qur'ānic Vocabulary}

Although the story itself does not evolve from the Qur'ānic text, its vocabulary relates to several Qurānic contexts. First, it refers to the Qur'ānic Paradise story, through relating to Adam and Eve and to the Devil, their seducer and the cause of their expulsion from Paradise. ${ }^{12}$ Although the name Eve is not mentioned in the Qur'an, Islamic tradition is familiar with this name, which occurs in the Tafsìr literature. ${ }^{13}$ Also related to the Qur'ānic allusion to the Paradise story are Eve's reference to the Devil as "our enemy" ('aduwunā $),{ }^{14}$ Adam's accusation of Iblīs as the one who "deceived us"

(Banū Isrầ'll)"; or folklore considered as (or sometimes actually) borrowed from Jewish sources. The folklore and imaginary themes led to the condemnation of the Isrä'iliyāt by strict scholars and the classical collectors of the Hadith. The sources for this material are believed to have been converted Jews, or Muslims who had contacts with Jews and Christian in the pre-Islamic period. Wahb b. Munabbih is one of the notable names among such transmitters. G. Vajda, "Isrā̄illiyāt," $E I^{2}$, Vol. IV, pp. 211-212.

11 The advocates of free will (as opposed to pre-destination) in Islam. The earliest Qadarite document is the Risāla of Ḥasan al-Bașrī (d. 110 A.H., a contemporary of Wahb b. Munabbih), which argues that evil stems from human beings or from Satan, whereas God only creates good; and humans choose between good and evil. J. van Ess, “Qadariyya," $E I^{2}$, Vol. VI, pp. 368-372.

12 Q: $2 / 35-36,7 / 19-22,20 / 117-123$. It is worth noting, however, that in the Qur'ān the name of the Devil when he seduces Adam and his spouse in Paradise is al-Shayțān. The terms Iblīs and al-Shayțān are interchangeable, although some modern scholars try to make a clear distinction between them. See: Allouche, "Images of the Devil," pp. 15-17.

13 The Devil (Iblīs) tempts Hawā' (Eve): Qurțubī, Tafsīr, Vol. 1, p. 313 (Q: 2/36); Ṭabarī, Ta'rīkh, Vol. 1, p. 72. The Devil (al-Shayțān) tempts Hawā' (Eve): Suyuṭi, Al-Durr al-Manthūr, Vol. 3, p. 428 (Q: 7/20-25); Ṭabarī, Ta'rīkh, Vol. 1, p. 73.

14 See for instance Q: $2 / 36,7 / 22,20 / 117$. 
(gharranā) $)^{15}$ the expression "entirely" (jamic(an) expulsion of Adam and his spouse from Paradise; ${ }^{16}$ and the verb waswasa, which is the verb used to describe how the Devil (al-Shayțān) seduced Adam and his spouse to eat from the forbidden tree. ${ }^{17}$

The verb (waswasa) also appears in süra 114 (al-Nās), which is the main Qur'ānic reference relating to this report. The terms Khannās, șadr, yuwaswisu and inkhanasa, which appear in the text of the report, all connote with the vocabulary of this sūra:

I seek refuge in the Lord of human beings, the King of human beings, the God of human beings, from the evil of the retreating Devil ( $\mathrm{min}$ sharr al-waswās al-khannās), who whispers in people's breasts in an insinuating manner ('lladhì yuwaswisu fì șudūr al-nās); from the evil spirits and the [evil] people. ${ }^{18}$

But at the same time, whereas some of the Qur'annic elements, such as the references to Adam and Iblīs, are essential components of the plot, the story can do without the vocabulary from süra 114. Indeed, the folk tale versions of the story omit these elements. The son is called "little Devil". As will be shown below, ${ }^{19}$ while the last sentence of the Jewish-Yemenite version, after the Devil expresses his satisfaction at his son being eaten by Adam and Eve, speaks of the little devil who constantly occupies humans with thoughts, the last sentence in the Palestinian version does not refer to any seductive whisperings or human breasts. It is said only that "And since that incident, all human souls have come to contain an amount of good and an amount of evil or devilry". ${ }^{20}$

This suggests that the vocabulary of süra 114 may have been added to an existing text, in order to use it as an exegetical story; or maybe as part of "Islamizing" the story. This option is supported by the fact that the last sentence of the report combines elements (vocabulary and images) of other exegetical traditions to this süra. According to one of them, the expression

15 Q: 7/22 (referring to al-Shaytān); see also in relation to al-Shayțān Q: 4/120 (in relation to the non-believers) and 17/64 (in relation to al-Shayțān seducing humans until the Day of Judgement, when he will be punished).

16 Q: 20/123.

17 Q: $7 / 20,20 / 120$.

18 Q: $114 / 1-6$.

19 See section II below.

20 Ashhab, Kān Yā Mā Kān, pp. 188-189. 
al-Waswās al-Khannās in sūra 114 refers to the Devil (al-Shayțān), who puts his mouth on the heart (qalb) of a human being (ibn Ádam); when the human being is neglectful and forgets (sahā wa-ghafala), he seduces (waswasa), and when [this person] remembers Allah the Devil retreats (khanasa). ${ }^{21}$ This report correlates with the last sentence of the Khannās report, which begins "He [Khannās] devours (multaqim) the heart of [each] son of man [ibn Ādam]; as long as [the man] is neglectful [ghäfil(an)]." Alternatively, when the human being forgets [God], al-Shayțān devours his heart (iltaqama qalbahu). ${ }^{22}$

The exegesis to sūra 114 also suggests the interpretation of al-Khannās as the son of the Devil. As opposed to traditions such as those above which identify al-Waswās al-Khannās as The Devil, others consider al-Waswās as a descendant of the Devil: "When al-Waswās was born, al-Shayțān khanasahu, [that is] when Allah is remembered, [al-Waswās] 'withdraws', and when Allah is not remembered he sits tight in the heart [of the human]. ${ }^{23}$

Finally, kafala - the verb that is used by Iblis each time that he brings Khannās to Eve (ukfulīhi-look after him), appears in the Qur'ān in sūra 3:37, in the context of Zakariyya $\bar{a}^{24}$ looking after Maryam (Mary), the future mother of 'Isā (Jesus), because she had no father. Here one notes an opposite situation. Rather than blessed, it is problematic: whereas the Qur'ān tells of a man looking after a girl, here a woman is looking after a boy; and rather than the future mother of Christ, the child is the son of the Devil.

\section{The Roles of the Text in the Hadith}

As well as evoking theological and philosophical questions, this story also serves other goals and purposes in the different contexts in which it has been related.

21 Ibn Hajar, Taghlīq al-Ta lìq, Vol. 4, p. 382 (sūra 114). See also Ibn Hajar, Taghlīq al-Ta lì , Vol. 4, p. 381 (quoting Ṭabarī) and Ṭabarī, Tafsìr, Vol. 30, p. 355 (sūra 114), for another version of this report.

22 Ibn Kathīr, Tafsìr, Vol. 4, 576, sūra 114. Haythamī, Majma' al-Zawā’id, Vol. 7, 149. Abū Ya lā, Musnad, Vol. 7, p. 278.

23 Bukhārī, Șahịh, Vol. 4, p. 1904 (kitāb al-Tafsìr, sūra 114). Ibn Hajar, Fath al-Bārī, Vol. 8, p. 741 (quoting Ṭabarī and al-Ḥākim). Ibn Hajar, Taghlìq al-Ta lìq, Vol. 4, p. 381 .

${ }^{24}$ Father of John the baptist, considered in the Qur'ān as among the righteous. B. Heller [A. Rippin,] “Zakariyyā'," $E I^{2}$, Vol. XI, pp. 405-406. 


\subsection{Sūfì ideas}

Al-Hakìm al-Tirmidhī uses this text to illustrate his discussion of the ego (nafs), the evil inclination and its continuous presence within humanity.

The end of the Khannās report, which portrays the Devil's son, whom Adam and Eve thought was dead, as alive and active within their bodies and devouring their hearts, corresponds with one of al-Hakīm al-Tirmidhì's views of the nafs. According to Tirmidhī, the nafs is the centre of human impulse and desires, which are opposed to everything that is divine. Whereas the human rūh (spirit), qalb (heart) and 'aql (mind) are directed towards the celestial sphere, the nafs is ambivalent. One can, with much effort, educate and purify the nafs, make it more similar to the rūh, qalb and ' $a q l$, and bring it closer to God; however, its natural tendency is to sink down, towards the earthly. This is why humans, too, have a double nature. In his autobiography (Kitāb Sïrat al-Awliy $\bar{a}^{\prime}$ ) Tirmidhì describes how the nafs misleads human beings, by pretending to be dead. As a person stops being aware of it, the nafs misleads the believer from within - which is what happened to Adam and Eve after killing the Devil's son in the story. ${ }^{25}$

In the specific context of this story, the views of al-Tirmidhī regarding the nafs correspond with the symbolism of the child figure. According to C.G. Jung, the child is a symbol of the nascent Self ("the central nucleus of the personality which contains all the archetypal potential with which an individual is innately endowed"), and always points to the future and carries within itself the seeds of its own maturity and completion. A child must have a mother/mother substitute as an infant. However, this tie must be loosened in puberty. The child symbol means "evolving towards independence" says Jung. The child has thus to be detached from his origins - thus the ordeals suffered by child gods and young heroes. In all child myths he is on the one hand delivered helpless into the hands of terrible enemies and in danger of extinction, on the other has powers exceeding those of ordinary humans. This represents the urge of all beings to realise themselves. ${ }^{26}$ In the Devil's son story, the consumption of the Devil's child (the concluding part of the ordeal that this child goes through) is part of the development of the human psyche. He is (literally) cut from his substitute mother (Eve), but despite his helplessness this child has a supernatural ability to

25 B. Radtke, John O'Kane. The Concept of Sainthood in Early Islamic Mysticism, pp. $45-46 ; 191$.

26 Stevens, Ariadne's clue, pp. 235-240, 318. 
resurrect himself each time anew. Within the human breast, he constitutes the seeds (potential) of evil and inflated ego.

\subsection{An exegetical text: interpreting Q: $114 / 4-5$}

Al-Qurțubī, the commentator who links this text in his commentary to süra 114 (al-Nās), quotes it from al-Ḥakìm al-Tirmidhì. Qurțubī uses it to explain the expression al-Waswās al-Khannās (Q:114/4): the meaning of this phrase, its relationship to the Devil (Iblīs), and how did al-Waswās al-Khannās get to whisper seductively in people's breasts. According to the story, Khannās is the son of Iblīs. His presence and seductive whisperings in human breasts are the result of an incident involving his father and the father of humanity. Furthermore, al-Qurțubī, known for his support of the reality of demonic possession, ${ }^{27}$ quotes this story without further discussion. For his purposes, the text speaks for itself.

\subsection{The report as reflecting normative messages}

In addition to Qur'ānic and Hadith vocabulary, this report also reflects more general concepts, which are common to the Islamic Tradition. One of them is that the Devil dwells within human beings. A similar idea is reflected, for instance, in a common saying of the Prophet, according to which the Devil (al-Shayțān) flows in humans the way their blood does. ${ }^{28}$

Another Islamic concept is that anger should be avoided, for it is of the Devil. As will be shown below, Adam's anger had a lot to do with the unfortunate results of this incident. The idea of anger as a thing of the Devil is repeated in a number of traditions. For instance, "Anger is of the Devil, the Devil is made of fire; fire is turned off with water. If any of you is angry he should undergo ablution." 29 This idea relates to the view that human

27 See for example his exegesis to Q: $2 / 275$, which he interprets as speaking of the Devil as causing epilepsy. Qurțubi considers this verse as a proof for the reality of demonic possession. Qurțubī, Tafsìr, Vol. 3, p. 355 .

28 Inna al-Shayțān yajrì min ibn Ādam majrā al-damm. Bukhārī, Șaḥ̄ḥ, Vol. 2, p. 717; Vol. 3, p. 1195; Vol. 6, p. 2623. Muslim, Șaḥịh, Vol. 4, p. 1712. Tirmidhī, Sunan, Vol. 3, p. 475; Vol. 2, p. 411. Ibn Māja, Sunan, Vol. 1, p. 566. Ibn Hibbān, Șaḥ̄ḥ, Vol. 8, p. 428; Vol. 10, 347. Țabarī, Tafsïr, Vol. 1, p. 239 (Q:2/36). Qurțubī, Tafsìr, Vol. 1, pp. 301, 313 (Q: 2/36). Ibn Kathīr, Tafsìr, Vol. 1, p. 225 (Q: 2/187).

29 Aḥmad, Musnad, Vol. 4, p. 226. Bayhaqī, Shacb al-Imān, Vol. 6, p. 310. See also Ṭabarānī, Al-Mu jam al-Kabìr, Vol. 17, p. 167. Shaybānī, Al-Āhād wal-Mathānī, Vol. 2, 464. "In time of anger one should seek refuge in Allah from al-Shaytān al-Rajīm": Țabarānī, Al-Mújam al-Ṣaghïr, Vol. 2, p. 197. 
behavior affects demonic presence and actions. That is, even though the Devil is within the human heart, the choice of right and wrong is still maintained. ${ }^{30}$ The story also refers to the prohibition in Islam on the abuse of the dead.

Finally, this report supports the preservation of the existing social order, as it condemns violations of traditional conventions regarding the normative social roles of women. Adam's words to Eve "Did I not tell you not to obey him ..." express a demand that a woman should obey her husband. ${ }^{31}$ Disobedience might lead to undesirable results, as in this case. A deviation from the normative social role of a woman is also expressed through the role that Eve takes upon herself in looking after Khannās. Such a role is usually preserved for men, as in the Qur'annic example of Zakariyyā and Mary. ${ }^{32}$

In the context of folk literature, this story serves as an aetiological myth, which explains the origin of evil. This function of the text will be further discussed below.

Despite its normative messages and its exegetical role, this report failed to gain popularity in the Hadith, whereas the existence of popular versions, as well as the inclusion of this story in anthologies of folk literature, strongly indicate of the great popularity and circulation that this story gained as a folk tale. A possible explanation for its rejection from the scholarly literature emerges from the discussion below.

\section{The Text as a Folk Narrative}

\section{Structural Characteristics: An Analysis According to Olrik's Epic Laws}

Finding a folk tale version of the Khannās report should not come as a surprise. The Hadith report itself is similar to a folk narrative, ${ }^{33}$ and corresponds

30 Compare for example with the Hadith report according to which a person who wakes up and goes to the market is accompanied by the Devil, whereas those who wake up and go to the mosque are accompanied by an angel. Shaybānī, Al-Āhād wal-Mathānī, Vol. 5, p. 183.

31 Q: 4/34: “... The good [women] are obedient...”

32 Q:3/37: "[...] and Zakariyyā looked after her".

33 The motif of a child cooked and eaten by his parents is found in folk tales. For example, in the story of "The Juniper Tree" a child is killed and cooked by his step mother, and eaten by his father. The motifs that are shared by the two stories 
to many of Olrik's Epic Laws. ${ }^{34}$ For instance, the story consists of three episodes, which follow a repetitive pattern (The Law of Three; The Law of Patterning). There are repetitive expressions, such as when Iblis gives Eve the child, and tells her to "look after him" (Ukfulïhi) (The Law of Repetition). Each scene contains two characters only (The Law of Two to a Scene), and the principal character of each such couple (either Iblīs or Adam) appears first (The Law of the Importance of Final Position).

On the other hand, the story seems not to correspond to the essential Law of Contrast, according to which "The Sage is always polarised": 35 rich and poor, good and evil, wise and foolish. This law is an essential element in folk narratives; but it is exactly this contrast which is missing in the story. Whereas on the one hand Ibliss (being the Devil) is known to be evil, on the other Adam and Eve can hardly be viewed as role models-Adam with his cruelty against Khannās, and Eve who three times accepts the responsibility for looking after a child, and then neglects it. It is only in the last sentence of the story, that a contrast is presented in terms of a cosmic struggle between God and the Devil: whenever Allah is remembered, Khannās retreats. However, this contrast is not reflected in the story itself, in which God is not mentioned. The last sentence seems as an addition to the story, not only because it appears to be a composition of exegetical traditions to sūra 114, as suggested before; but also since, from a literary perspective, it does not fit with the rest of the narrative. Rather than a succession of actions or a dialogue, it is a descriptive sentence, in which the narrator's voice is heard.

It should be noted that, the previous laws, to which the story corresponds, have to do mainly with its structural characteristics, whereas the latter one deals also with the characters. Thus, a characters analysis might,

are the step mother; the killing, chopping and eating of the child; the tree; the fire; salty water (here: tears, rather than the sea); and the resurrection of the child. Grimm's Fairy Tales, pp. 220-229 (story 47).

34 Axel Olrik (1864-1917) was a Danish folklorist. By the thirteen Epic Laws (1909) he wished to characterise all folk narratives. The laws remain effectual to these days, although some of them have not been found always applicable for folk narratives outside Western Europe and the Semitic tradition. The text under consideration, however, seems to fit well with most of them. Axel Olrik, "Epic Laws of Folk Narrative," in Alan Dundes (ed.), The Study of Folklore, Englewood Cliffs: Prentice-Hall, 1965, pp. 129-141. Trans. by J.P. Steager. [Originally published in 1909]. Chesnutt, "The Many Abodes of Olrik's Epic Laws," pp. 7-11.

35 Olrik, "Epic Laws of Folk Narrative," p. 135. 
therefore, give different results. For that purpose, the story should be read independently, regardless of its religious context. Its hero should be Iblīs.

After abandoning the concept of Iblīs as evil by definition (as in the religious framework), it is possible to view Iblīs as morally neutral, or even good, and Adam and Eve as evil. He gives them his son to look after, and they kill him, time after time, out of revenge. For this behaviour they receive eternal punishment. Although Adam is the initiator of this, Eve is guilty of betraying her responsibility to look after the child.

Nevertheless, one could say that at the peak of horror, when Adam turns Khannās into dinner, Iblīs shows his true colours: this was exactly what he was hoping for. The negative references made to him throughout the plot ("our enemy", deceiver, accursed) are not in vain: it is he who has no mercy on his own son, whom he sacrifices in order to achieve his goal. The apparent contrast in the story goes through a certain twist towards the end, when Adam's behavior becomes understandable; nevertheless, one cannot help thinking that had Adam been less angry and vengeful, he would not have fulfilled Iblīs' scheme so faithfully. The question of contrast remains, therefore, undecided. The folk tale versions of this story try to avoid this lack of clarity, and follow the Law of Contrast. As a folk narrative, the text was told during the twentieth century in two contexts: one is Jewish-Yemenite and the other is Palestinian. From the very beginning, the Palestinian version presents the plot of Iblīs to the audience:

\section{The origin of evil in humanity ${ }^{36}$}

It is told that our father Adam was busy that day taking care of the woods, while our mother Eve was doing her chores in the cave where she lived. Suddenly, she heard a voice crying and rushed out of the cave towards it, and to her great surprise she saw a pretty, naked baby crying.

36 Ashhab, Kān Yā Mā Kān, pp. 188-189. Collected from Mārī Salīm Hanā, Jerusalem, 1979. From among the different versions of the Palestinian folk tale I chose to quote this one, since the one collected by Hanauer in 1934 (which is almost identical to this version, although the two versions were collected by different writers and from different people), was collected in English. Sirhan, who quotes Hanauer's version in his book, does not give an accurate translation of the story into Arabic. The main difference is that in Sirhan's translation Hawä' takes care of the child three times, whereas in Hanauer's version she is only said to have taken care of him on the first day. Perhaps Sirhan was familiar with another version of the story, which 
Eve did not realise that this little baby was the son of Iblīs, [and that] his father had sent him to start tempting Adam and Eve and their offspring on Earth. Eve carried it as she felt sorry for it, and pampered it until it became quiet.

When Adam came home from his journey, he saw the baby in her hands, took it away from her angrily, and went to the river bank, then threw it into the water and watched it sink, then he left it and returned to the cave and warned Eve about it.

The next day, after Adam left for his work, Iblīs came to the river and called his child: "My little Ifrit, where are you?" [The child] replied while floating on the water: "Here I am, father". [Iblīs] commanded him to wait for him on the bank until he came back and called him.

At the end of the day Adam saw him there, and noticed that he was a beautiful creature, however he was not deceived by that, but carried him and threw him in the fire until he was turned into ashes.

On the morning of the next day Iblīs came and called his son, and immediately life returned to him and when the father of humanity returned to the cave at the end of the day he saw in front of him the little devil playing, although he was certain that he had killed him once by drowning him and a second time by burning him, and he began to think of a way to finally get rid of him, and told Eve angrily: "The best solution to get rid of that accursed devil is that we slaughter it, cook it well and then eat it".

Indeed, they executed this way [of action] and ate all of it. When the head of demons came on the morning of the next day he called his child and said: "Where are you my little devil?" And two voices came out from within the bodies of Adam and Eve and replied: "I am here oh father, happy and enjoying peacefully". And so Iblīs said to him "Good that is exactly what I planned for them and wanted for you".

And since that incident, all human souls have come to contain an amount of good and an amount of evil or devilry.

The statement that Iblis had sent his son in order "to start tempting Adam and Eve and their offspring on Earth" makes the audience view

he combined into Hanauer's version. The translation given here is my own, since the translation of Ashhab's book into English is more of a paraphrase. E.J. Hanauer, Folklore of the Holy Lands, p. 12; Nimr Sirhan, Al-Hikāya al-Sha biyya al-Falastīin̄yya, p. 108; Ashhab, Popular Stories from Palestine, Jerusalem: The Arab Studies Society, 1987. See also: This Week in Palestine-Story of the Week [online]. Jerusalem Media \& Communication Centre (JMCC), February 2000 [cited November 06 2010], $<$ http://thisweekinpalestine.com/details.php?id=703\&ed=63\&edid=63>. 
Adam's actions in the light of this already-known scheme. Eve, who finds the child as an abandoned baby, is neither obliged to Iblīs, nor does she know of his relation to it. At the same time, Adam seems to have the knowledge of the "baby" being a devil in disguise. Picturing the child as demonic from the very beginning justifies Adam's behavior towards him. ${ }^{37}$ This way, the story retains the typical characteristics of a folk tale, and gains popularity, for the loss of some of the twist and the tension that the religious text offers. In the Jewish-Yemenite version the contrast is even clearer, as it replaces the child with a sheep:

\section{How did the Devil enter the human heart ${ }^{38}$}

When the first man was still in this world, the Devil was not in his heart. Then the Devil came to him in the form of a human being, and his son he made into the shape of a sheep. He came and said: "I leave the sheep with you for a year, for you to look after it for me. After one year I shall come and take it".

"Fine".

The Devil left and did not return for one year. The man waited and waitedhe saw that the other one was not coming - he went and slaughtered the sheep. He and Eve ate it. Said Adam: "That man will come, we shall tell him: it ran off, or died and that is it!" The following day, as soon as they had eaten the sheep, the next day the Devil came. "Give me my sheep". "It ran off. What can I do?"

"Not true, it did not run away".

"Yes it did!"

"And if I call it and it answers, then what?"

"I'll see you call!"

The Devil called:

"My son, where are you?"

"Here, father" replied the little devil, "in the stomach of man. Should I come out?"

"No, no. Stay!"

37 Ibid.

38 Schwili, pp. 158-159. 
And so the little devil remained within the human heart, and did not let him have peace - all time long man has thoughts.

Adam is not aware that he is speaking to the Devil, and faithfully fulfills his obligation to look after the sheep. Only after the man fails to return in due time, does Adam decide to slaughter the sheep and eat it. He is innocent of anger and vengeance. Once the identity of the "good guys" and "bad guys" becomes clearer, the audience can take side with one of the characters, which makes it easier it to accept the story (especially in a version that speaks of eating a sheep, rather than a child). It should be noted that, in this version, unlike the scholarly hadith version, or even the Palestinian version of the folk tale, Eve is completely passive. This leaves Adam and the Devil as the only active figures, and emphasizes the contrast between their characters.

That said, the folk tale versions, too, still preserve negative characteristics in Adam's image: in the Jewish-Yemenite version Adam lies brazenly, and to a certain extent it seems that the eventual outcome of the narrative is the ramification of it. The Palestinian version preserves two attempts at murder, as well as the motif of Adam's anger. This ambiguity of the Law of Contrast, which is an essential characteristic of folk literature, could be seen as supporting the view that this story originates from a written, rather than an oral, source; however, this is hard to determine.

\section{The Role of the Text as a Folk Narrative}

\subsection{The text as an aetiological myth}

As a folk narrative, the text belongs to the genre of myth. The title of the Palestinian version, "The Origin of Evil", ${ }^{39}$ reflects its role as an aetiological myth. As such, the story seems to claim that the origin of evil is external to human beings. The guilt for its entry into humanity lies with Eve, who let the Devil into the house. Had she not obeyed Iblīs, this would not have happened.

However, a closer look reveals that it was Adam's choice of actions that led to the unfortunate results. Although he read Iblīs' intentions correctly, his reaction was wrong; had he been less violent, less furious and avenging, he would not have killed the child in the first place, and would not have come to the act of eating it. Iblīs was only using an existing potential, which he helped to develop into action. Evil was within Adam all along, in the

39 Ibid. 
form of anger. The anger that led Adam in his actions and his tendency to evil are shown in the increasing violence of his actions. The first time he comes home, speaks to Eve and then decides on the killing; the second time he does not bother to ask questions; the third time, he intentionally plans the killing. This is no longer a chance act of murder, but a planned one. Taking the risk of pushing it a little, Iblis' influence could also be seen in the ways that Adam uses for killing Khannās: the sea is where Iblīs' throne is, and the fire is what he is made of. The trees might stand for the tree of Paradise; here, however, rather than pick a fruit from a forbidden tree as in Paradise, Adam "adds" a forbidden fruit to the tree. The view that Evil is immanent to human beings is known to the Islamic tradition. It is expressed, for instance, in the above-related saying of the Prophet, that the Devil flows in humans as does their blood. ${ }^{40}$ However, while conveying that view, the story puts Adam (whom Islam regards as a Prophet), in a rather negative light. Similarly, the title of the Jewish-Yemenite version, "How did the Devil enter human heart," apparently states unambiguously that evil has entered into humans from without; but Adam's questionable behavior, combined with Eve's passivity, re-opens the question of the origin of evil, leaving us without a clear answer.

Another possibility is to see Adam as a tragic character. Although he is aware of the danger, and takes extreme measures against it, it is exactly these measures which draw him ever closer to his enemy — or rather, his enemy ever closer to him: he is destined to be evil. This interpretation, like the first one, takes the responsibility off Adam's shoulders, for there was nothing he could do about it, no matter how hard he tried. This is indicated in that the ways he uses for killing the Devil's son always involve spreading him around (= spreading evil around): hanging his corpse on a number of trees; spreading his ashes in the sea; and having him eaten by the protoplasts, through whom he was spread to all humanity. Whereas Adam's first two attempts to get rid of the child were directed outwards (trees: high up, and sea: deep down), the third, crucial step was directed inwards (inside his and Eve's bodies), and caused evil to be spread among all of humankind.

The ways in which Adam chooses to kill Khannās also relate to the elements, directions and dimensions of the world. When he cuts the child into four and hangs him on four different trees, this refers to the four directions: North, South, East and West. The trees (high) stand for the air, the sea for water, the burning incorporates fire, and when Adam and Eve consume

40 See note 28 above. 
the child he goes back to earth, from which humans were created (Biblical etymology of Adam is adama - earth) — the four elements. This prevalence of the number four correlates with the significance of the quaternity as an archetype of totality, both in nature and the psyche, according to Jung. ${ }^{41}$ Furthermore, when, on his first attempt, Adam hangs the child on a tree (a symbol of life, aspiration and Heaven), he looks up to the sky, to the (spiritual) air of the divine realm, from which Adam and Eve have fallen due to the Devil. However, the roots of the trees are in the ground, they are connected to the (material) earth, and symbolise the underworld and the demonic. When Adam spreads the child's ashes in the sea (a symbol of the unconscious psyche), he looks deep inside. The fire with which Adam burns and roasts Khannās is a symbol of transformation, consciousness and sex. ${ }^{42}$ And when he and Eve eat the child, they consume his flesh, which stands for lust and materialism. This description therefore suggests the gradual deterioration of Adam, as he lets his anger and vengeance take him over.

\subsection{The text as a reflection of its narrative circumstances}

Just as in the scholarly Hadith literature, as well as in a folk tale, the circumstances in which the Khannās story has been told are significant for a better understanding of its meanings in a given context. It is notable that the Jewish-Yemenite version differs from the Islamic versions (both literary and popular) in that it replaces the child figure, later slaughtered and eaten, by a sheep. The narration of this milder version of this story in Yemen during the first half of the twentieth century might very well appertain from the great famine of 1905 in the city of Șan ‘̄a', following a three-year drought and the siege of the city by Imām Yahyā, as part of his struggle against Ottoman occupation. ${ }^{43}$ The Yemenite-Jewish writer, Rabbi Sulaymān Ḥavshūsh, says about the results of this siege:

The Gentile butchers would secretly slaughter dogs and donkeys and sell them as meat of sheep and camels. When the poor among the Jews needed [meat] they would buy [this] meat for frying, thinking that it was of bulls or sheep, I saw it with my own eyes. And some of the Gentiles would steal the children of their friends and eat them, as one would tear a kid. ${ }^{44}$

41 Jung, $C W 11, \S 246 ; C W_{116}$ §405.

42 Stevens, Ariadne's Clue, pp. 113, 124-128, 379-380.

43 Eraqi Klorman, p. 205.

44 Ibid. 
Similarly, the Yemenite historian al-Wāsi'i tells us that during the siege, some people killed (dhabaha) their daughters and ate them. ${ }^{45}$

The Devil's son in the guise of a sheep in the Jewish-Yemenite version might relate to the fowl meat that had been unknowingly consumed by some Jews during this period. At the same time, in a society where such incidents occur that "cause the listener a dismay," ${ }^{46}$ in al-Wāsi'î̀s words, it would seem natural that, on the one hand, such a narrative would appear, while on the other hand, it would seem even more natural that the explicit motif of cannibalism would be blurred.

The Palestinian version was transmitted orally throughout the twentieth century. It was collected in 1935 and 1979 by two different writers, from diverse sources in various parts of the country, and quoted in a study of Palestinian folk literature in $1988 .{ }^{47}$ This implies that the story is still alive and relevant today in this area. According to this version of the story, when Eve took the baby she was not aware of its true nature, and thus she unknowingly introduced evil into her house. Adam, on the other hand, recognised the nature of the baby right away. When Adam committed an act of cannibalism to get rid of the baby, it was an act of total extermination of the child but, at the same time also of a total assimilation of it into the bodies of himself and Eve. From this perspective, the story in its Palestinian context could reflect a Palestinian view of the geo-political changes during the twentieth century in the area of Palestine and Israel and the Middle East in general.

\section{The Story of the Devil's Son in Comparison with Other Religious Stories}

\section{Heaven on Earth: the Son of Iblis and the Story of Paradise}

A comparison of the Khannās report with the Paradise story is almost self evident, as both involve Adam and Eve, who are both tempted by the Devil to eat something which they know is forbidden.

45 Wāsi'ī, Ta'rīkh al-Yaman, p. 20o. I would like to thank Dr. Bat-Zion Eraqi Klorman for drawing my attention to the famine of 1905 in Yemen, and to the relevant sources.

46 Wāsi'ì, p. 205.

47 E.J. Hanauer, Folklore of the Holy Lands, p. 12; Ashhab, Kān Yā Mā Kān, pp. 188-189; Sirhan, Al-Hikāya al-Sha'biyya al-Falasținìyya, p. 108. 
In the Qur'ānic Paradise story in sūra 7 ( $a l-A$ 'räf), God forbids Adam and his spouse to approach a certain tree, lest they become of the unjust ( $\mathrm{min}$ al-zäliminn). The Devil (al-Shayțān) tempts (waswasa) them to violate this command. The act of eating makes them go through a transformation that makes them realise their shame. As a punishment for their disobedience, God banishes them eternally from Paradise. ${ }^{48}$

Süra 20 (TTha) has a somewhat different version of the story. Here, God speaks to Adam not of the tree, but warns him of Ibliss, who is "an enemy ('aduw) to you and to your spouse. Don't let him get you out of the garden" (Q: 20/117). Then al-Shayțān seduces (waswasa ilā) Adam and tells him of the tree. Both Adam and his spouse eat of it, and go through an essential internal transformation, that makes them realise their shame. God then banishes them from the garden altogether $\left(\mathrm{jami}^{\left.-c^{(a n}\right)}\right)$.

In this context, the story of the Devil's son can be interpreted in two ways:

(1) As the main character of the story-Adam ("God") orders Eve ("Adam") not to obey Iblīs. Iblīs tempts her to disobey this command and to accept his son. She thus lets Iblīs (through his son) into their house, which eventually leads to the eating of Khannās by Adam and herself. This causes an essential transformation within them, from which humanity will forever suffer.

Such a reading is compatible with the süra 20 (Țaha) version. In both stories, the order is to keep away from Iblīs. Eve is tempted, and both she and Adam eat something that is forbidden, acquired through wrong doing and causing an immediate and eternal transformation of essence. The transformation through which they go is worse here, as is also reflected in the symbolic nature of what they consume. Rather than a divine fruit (a plant symbolising purity), it is the corpse of a murdered demonic creature (flesh is equated with lust).

However, the parallel is not complete, since Adam, who according to this interpretation parallels God (as the law-giver), is also at the same time among the erring and the punished. He makes wrong decisions, which eventually result in carrying out Iblīs' plan.

(2) As the main character of the story, we find Iblīs-A second possible reading of the text would have Iblīs ("God") commanding Eve ("Adam") to secure his son. Adam's ("Iblīs") desire for revenge, resulting from a past incident (the expulsion from Paradise), leads him to harm the child. Eve

48 Q: 7/19-24. 
cooperates with him. Eventually, Adam takes the child's life and consumes the body, the forbidden food, together with Eve. For this their essence is transformed, and they are punished by the eternal presence of Iblīs' son in their bodies, eating them from within. As against the eternal separation from Paradise and its fruit, here they are eternally bound to Khannās: eternal presence versus eternal absence. Adam fits well in the role of Iblīs who, in causing the expulsion of Adam and Eve from Paradise, was also driven by his desire for revenge. ${ }^{49}$

Iblīs, as the law-giver (God), has knowledge which Adam and Eve lack. He can foresee their actions, and their punishment comes from him. Yet, as the last sentence of the story makes clear: the Divine knowledge remains superior to that of Iblīs. Whenever God is remembered, Khannās has to retreat.

A comparison of the two stories shows that there is more than one possible readings of the Khannās report. Like the folk tale analysis, here too the more likely reading is the one giving Iblis the better role.

Another association between the Paradise and the Khannās stories is through the verb hayiya (which means both to live, and to be ashamed). In Q:7/25 this verb refers to the earthly life of Adam and Eve, after God has banished them from Paradise. ${ }^{50}$ In the Khannās report related by Tirmidhī, this verb relates to the resurrection of Khannās, the Devil's son, after Adam has killed him. The Arabic word hayya (a snake) also derives from this root. According to Jewish and Muslim tradition, the snake was the disguise through which Satan/Iblīs entered Paradise to tempt Adam and Eve, after God had already expelled him. ${ }^{51}$ Here, Khannās (i.e. the Devil's son) is the disguise through which Iblīs enters Adam and Eve's home on earth. One should note that the sound of the term Khannās bears a certain similarity to hanash (Arabic) or nahash (Hebrew), also meaning 'a snake'. The name

49 It was due to the refusal of Iblīs to bow before Adam, that God deported him from heaven. Iblīs asked for (and received) a postponement of his punishment to the Day of Judgement. In the meantime, he seduces humanity away from the way of God. Q: 7/11-17, 38/71-83.

50 "On [the earth] you shall live, and on it you shall die, and from it you shall emerge".

51 The snake enters Iblīs to Paradise: Țabarī, Tafsīr, Vol. 1, p. 236 (Q: 2/36). Qurțubī, Tafsīr, Vol. 1, p. 313 (Q: 2/36). Țabarī, Ta'rīkh, Vol. 1, p. 72. The same tradition exists also regarding al-Shayțān: Suyūṭi, Al-Durr al-Manthūr, Vol. 3, p. 428 (Q: 7/20-25). In Jewish tradition: Ginzberg, Legends of the Jews, Vol. 1, p. 94. 
Hawā' (Hebrew: Hava) also derives from the root hyy (in Hebrew), and its Biblical etymology is em kol hay - the mother of all living creatures. ${ }^{52}$ However, "Hava" "also connotes with the Hebrew word hiv $\bar{a} \vec{\imath}$ (a kind of snake) and in the context of the present text, in which she looks after Khannās, Eve could very well be described as "the mother of all snakes". Indeed, in the story about Cain as the son of Eve and Satan, Satan is described as riding the snake, or himself being the snake, during the act. ${ }^{53}$

\section{Fathers and Sons: Iblīs and Khannās, God and Jesus, Abraham and Isaac}

Pushing the casting of Iblīs as the story's hero a bit further, the Khannās report can be seen as a story of a father, who sacrifices his son for the sake of a supreme goal. Two such stories are well known in the Biblical context.

\subsection{Abraham and the sacrifice of Isaac}

The significance of the sacrifice motif in the story of the Devil's son is evident through the use of the verb "to sacrifice" (dhabaha, Hebrew: shahat), which appears in both the Biblical and Qur'ānic narratives of Abraham's sacrifice of his son, in all versions of this story. ${ }^{54}$

In the Bible, Genesis:22 tells us of God's command to Abraham to sacrifice his beloved son, Isaac. Abraham obeys the divine command. However, at the very last moment God stops him from killing Isaac and Abraham sacrifices a ram instead. ${ }^{55}$ God rewards Abraham for his obedience, blesses him and promises to multiply Abraham's seed and make his seed a blessing for all nations. ${ }^{56}$

As in the Biblical story of the sacrifice, and in the story of the Devil's son, the sacrifice of the son gains eternal life for the father through his seed, who now lives forever within the breast of human beings. However, whereas Abraham's seed is a blessing to humankind, the Devil's offspring is a curse. Another contrasting parallel between the two narratives is found in the dialogue between Abraham and Isaac, against that of Iblīs and Khannās (in the Tirmidhī version): Whereas the Biblical narrative has Isaac approach

52 Genesis 3:20.

53 Pirkey de-RabbīEli'ezer- "Horev", chapter 21 4-5; Zohar, Vol. 1, p. 28b; Kugel, The Bible As it Was, pp. 86-87; Urbach, Sages, p. 147.

54 Genesis 22:10 "And he took the knife to slay his son"; Q:37/102, 107.

55 Genesis 22:1-13.

56 Genesis 22:17-18. 
his father, who replies "Here I am", ${ }^{7}$ in the Khannās narrative it is Iblīs who calls his son, and Khannās answers him "Here I am". The sheep of the Jewish-Yemenite version of the story also connotes with the ram of Genesis 22.

In the Qur'ān, the story of al-dhabih is referred in Q:37/101-110 (al-Sāfät). In the Bible the sacrificed son is Isaac, whereas in the Qur'an his identity is unclear, and the commentators are divided in this matter between Isaac (Ishạāq) and Ishmael (Ismāêil). ${ }^{58}$

According to the Qurān, Abraham (Ibrāhīm) had a vision in his sleep, commanding him to sacrifice his son. He thus prepared his son to be slaughtered. When God appeared to him and told him that the dream had been fulfilled, Abraham made a big sacrifice to God in place of his son (according to the commentators, this was a ram or a goat). ${ }^{59}$ God blessed both Abraham and his son, and informed them that among their descendants would be both sinners and righteous people. ${ }^{60}$

Like the narrative of the Biblical sacrifice and the story of the Devil's son, here too the willingness of the father to sacrifice his son brings him benefit. In the Qur'anic story the son is also included in the blessing; however, whereas in the Bible the outcome of this willingness is entirely positive, the Qur'ann is ambivalent in this matter: as a result of the blessing righteous people and sinners are both to be born. This distinction among the descendants of Abraham and his son parallels the distinction in the scholarly version of the Khannās story between the situation of humans when they remember God and when they forget Him. In both texts, both situations are possible.

\subsection{God and Jesus}

Another case of a father initiating the sacrifice of his son is that of God and Jesus. Iblīs and Khannās can be viewed in this context as a negative reflection of God and His son. Both stories speak of spiritual entities, if one might say so, who give their son to a woman to take care of. Jesus, the son of God, is also called the "Lamb of God", "Son of Man" and "second Adam". 61

57 Genesis 22:6-8.

58 For an exhaustive discussion of the sacrifice story in the Qur'ān and Tafsīr see: Reuven Firestone, Journeys in Holy Lands, pp. 105-151.

59 Firestone, p. 131.

60 Q: 37/113. However, this verse refers specifically to Isḥāq.

61 Matthew: 12/8, Mark: 2/28, Luke: 6/5. 
Symbolically, Khannās, the son of Iblīs, who takes on the form of a sheep in the Jewish-Yemenite story, could also be considered the son of Adam, since he has been fostered by Eve, Adam's wife; and his eternal abode lies within the breast of the son of man (ibn Ādam). In both narratives the son is sacrificed by his father and killed by human beings. The sacrificed son is eaten by humans - the son of God by the disciples, during the Last Supper, ${ }^{62}$ and during the ceremony of communion (the bread and the wine of the communion are called the body and the blood of Christ) ${ }^{63}$ ever since (to remember Jesus); and the son of the Devil is eaten by Adam and Eve, in their final meal before their essence is transformed. The Devil's son has also been consuming the hearts of humans ever since (or at least of those who do not remember God). In both cases the son dies and is resurrected by his father, who foretells both the death and the resurrection. While God creates by the power of His word (His son is the logos), Iblīs, too, creates life (brings his son back to life) by the power of his word (the name of his son). Whereas the son of God dies, and after three days is resurrected ${ }^{64}$ and lives eternally with humans ${ }^{65}$ or in heaven, ${ }^{66}$ the son of the Devil dies three times. He is then resurrected and lives eternally within humans, on earth. Finally, in both cases the sacrifice of the son has a tremendous influence on human fate. However, whereas the sacrificial death of the son of God redeems humanity from original sin, the sacrificial death of the son of the Devil reconstructs the original sin, and curses humanity.

The comparison reveals divine-like qualities (giving life) that are attributed to Iblīs practices in this story. But whereas God uses His powers to redeem humanity, Iblīs uses it in order to make humans eternal damned. The Devil's son story thus seems to be not only ambivalent with regard to Iblīs, but also contains a number of dualistic elements.

\section{Summary}

The story of the death and life of the Devil's son is first and for most an aetiological myth, which deals with the question of the origin of human

\footnotetext{
62 Matthew: 26/17-29.

63 Matthew: 26/26-27.

64 Luke: $24 / 1-8$.

65 Matthew: 28/20.

66 Luke: 24/1-8, Matthew: 20/28.
} 
evil. That said, the story presents an ambiguous stance in this matter, and gives no clear answer to the question which it presents. Other topics with which this story deals, in the context of scholarly Hadith literature, have to do with the question of dualism, free will, religious and social norms, Qur'ānic exegesis and Șūfi ideas. Nevertheless, the circulation of this story as a Hadith report is very limited. Several reasons can be suggested for this. One of these is the dubious isnād of this report, although the identity of the transmitter might already reflect an earlier rejection of the text. Another possibility is the ambiguity of the story with regard to the position of Iblīs, while permitting an interpretation which sets the origin of Evil within Adam. Although this ambivalence served well Al-Hakìm al-Tirmidhï's ideas regarding the dual nature of the nafs, it also presented the prophet Adam in a non-flattering light. The circulation of this story might also be related to the question of its origin. Outside the Hadith, the story gained success as a folk tale. This, as well as its compliance with most criteria and characteristics of a folk tale, implies that it might have originated as a folk tale. One should keep in mind, however, that the folk tale versions of the story seem less controversial. Moreover, the story does not comply with the "Law of Contrast," which is essential to folk tales. Therefore, the question of its origin remains uncertain.

That the story has remained alive for over a thousand years (at least since the tenth century C.E.) and has preserved its oral form, indicates for the enduring relevance of the questions with which it deals. At the same time, each time it is told, the story is interpreted anew, in accordance with the specific context and circumstances of its narration.

Finally, the above discussion touched upon the intriguing relationship between the scholarly Hadith and folk literature. It would seem that folk literature, albeit of a different time and context, can prove helpful in the study and understanding of Hadith reports. This deserves further research.

\section{Works Cited}

Abū Ya'lā, Musnad-Abū Ya'lā, Aḥmad bin 'Alī bin al-Muthannā al-Mawṣilī al-Tamīmī (d. 307 A.H./919 C.E.). Musnad Abì Yålā. Ḥusayn Salīm Asad, ed. Damascus: Dār al-Ma'mūn lil-Turāth, 1984.

Al-Hakīm al-Tirmidhī, Nawādir al-Ușūl-Al-Hakīm al-Tirmidhī, Muhammad bin 'Alī bin al-Hasan Abū 'Abdāllah. Nawādir al-Ușūl fı̀ Ahạāìth al-Rasūl. Beirut: Dār al-Jīl, 1992 ['Abd al-Raḥmān 'Amīra ed.]. 
Allouche, "Images of the Devil”-Allouche, Zohar Shani. "'Between the milk and the froth': Images of the Devil in the Muslim tradition (Hadith)." Unpublished doctoral thesis. London University: October 2006.

Ashhab, Kān Yā Mā Kān-Ashhab, Rushdi (al-). Kān Yā Mā Kān: Hikāyāt Sha biyya min Madīnat al-Quds. Bir Zeyt: Dār 'Alūsh lil-Nashr, 2001.

Ashhab (al-), Rushdi. Popular Stories from Palestine. Jerusalem: The Arab Studies Society, 1987 .

Aḥmad, Musnad-Aḥmad bin Ḥanbal Abū 'Abdallāh al-Shaybānī (d. 241 A.H./ 856 C.E.). Musnad al-Imām Aḥmad bin Hanbal. Egypt: Mu’assasat Qurțuba, n.d.

Bayhaqī, Sha'b al-Imān-Bayhaqī (al-), Aḥmad bin al-Husayn bin 'Alī bin Mūsā Abū Bakr (d. $45^{8}$ A.H./1066 C.E.). Sha'b al-Imān. Muhammad al-Sa'̄ì Basyūnī Zaghlūl, ed. Beirut: Dār al-Kutub al-'Ilmiyya, 1410 A.H. (1989 C.E.).

Bukhārī, Șahīh_-Bukhārī (al-), Muhammad bin Ismā'īl Abū 'Abdallāh al-Ju'fì (d. 256 A.H./87o C.E.). Șahīh al-Bukhārī. Mușțafā Dīb al-Baghī, ed. Beirut: Dār Ibn Kathīr, al-Yamāma, 1987.

Chesnutt, "The Many Abodes of Olrik's Epic Laws"—Chesnutt, M. "The Many Abodes of Olrik's Epic Laws." Copenhagen Folklore Notes. Vol. 4/1999, pp. 7-11.

de Prémare, Alfred-Louis. "Wahb b. Munabbih, une figure singulière du premier islam." Annales: Histoire Sciences Sociales, mai-juin 2005.

E.J. Hanauer, Folklore of the Holy Lands-Hanauer, James Edward. Folk-lore of the Holy Land: Moslem, Christian and Jewish. London: Sheldon Press, [1935].

Eraqi Klorman-Eraqi Korman, Bat-Zion. The Jews of Yemen: History, Society, Culture. Raanana, Israel: the Open University, 2008. Vol. 3. [Hebrew]

Ginzberg, Legends of the Jews - Ginzberg, Louis. The Legends of the Jews. Rabbi Mordechai HaCohen, trans. and ed. Ramat-Gan: Masada, 1966 [Hebrew].

Grimm's Fairy Tales - Grimm, Jacob and Wilhelm. Grimm's Fairy Tales - Complete Edition. New York: Pantheon Books, 1944.

Haythamī, Majma' al-Zawā̇id-Haythamī (al-), 'Alī bin Abī Bakr (d. 807 A.H./ 1405 C.E.). Majma' al-Zawā’id wa-Manba' al-Fawā’id. Cairo, Beirut: Dār al-Riyān lil-Turāth, Dār al-Kitāb al-'Arabī, 1407 A.H. [1986 c.E.].

Heller, B. [A. Rippin.] "Zakariyyā'." EI². Vol. XI, pp. 405-406.

Ibn Hajar, Fatḥ al-Bārī-Ibn Hajar, Aḥmad bin 'Alī Abū al-Faḍl al-'Asqalānī al-Shāfīi (d. 852 A.H./1449 C.E.). Fath al-Bārī:Sharh Șaḥ̄h al-Bukhārī. Muhammad Fu’ād 'Abd al-Bāqī and Muhibb al-Dīn al-Khațīb, eds. Beirut: Dār al- Márifa, 1379 A.H. [1959 C.E.].

—, Taghlīq al-Ta līq —-Ibn Hajar, Aḥmad bin 'Alī Abū al-Faḍl al-'Asqalānī al-Shāfic̄

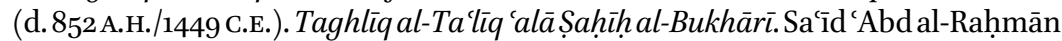
Mūsā al-Qazaqī, ed. Beirut: al-Maktab al-Islāmī, 1405 A.H., 1985 C.E.

—, Tahdhīb al-Tahdhīb - Ibn Hajar, Aḥmad bin 'Alī Abū al-Faḍl al-'Asqalānī al-Shāfīi (d. 852 A.H./1449 C.E.). Tahdhīb al-Tahdhīb. Beirut: Dār al-Fikr, 1984.

Ibn Hibbān, Șahịh —Ibn Hibbān, Muhammad bin Aḥmad Abū Hātim al-Tamīmī al-Bustī (d. 354 A.H./965 C.E.). Șahịh Ibn Hibbān. Shu'ayb al-Arnāùuț, ed. Beirut: Mu'asasat al-Risāla, 1993 .

Ibn Kathīr, Tafsīr-Ibn Kathīr, Abū al-Fidā' Ismā'īl (d. 774 A.H./1373 C.E.). Tafsìr Ibn Kathīr. Beirut: Dār Fikr, 1401 A.H. [1980 C.E.]. 
Ibn Māja, Sunan-Ibn Māja, Muḥammad bin Yazīd Abū 'Abdallāh al-Qazwīnī (d. 273 A.H./887 C.E.). Sunan Ibn Māja. Muḥammad Fu'ād 'Abd al-Bāqī, ed. Beirut: Dār al-Fikr, n.d.

IFA (Haifa). Text 1141. "How did the Devil enter the human heart." Collected by Heda Jason from Yehuda Jefet Schwili (Yemen). Holon [Israel], Blokonim 227, on June $5^{\text {th }} 1959$ [Hebrew].

Khoury, R.G. "Wahb b. Munabbih." $E I^{2}$. Vol. XI, pp. 34-36.

Kugel , The Bible As It Was-Kugel, J.L. The Bible As It Was. Cambridge, Massachusetts \& London, England: Harvard University Press, 1997.

Muslim, Șahịh-Muslim bin al-Ḥajāj Abū al-Ḥusayn al-Qushayrī al-Naysābūrī (d. 261 A.H./875 C.E.). Șaḥ̄h Muslim. Muhammad Fu'ād 'Abd al-Bāqī, ed. Beirut: Dār Ihyyā' al-Turāth al-'Arabī, n.d.

Nimr Sirhan, Al-Hikāya al-Sha biyya al-Falasțin̄yya-Sirhan, Nimr. Al-Hikāya al-Shacbiyya al-Falasținnīyya. Beirut: Al-Mu'assasa al-Falasținiyya lil-Dirāsāt wa'lNashr, 1988.

Olrik, "Epic Laws of Folk Narrative"-Olrik, Axel. "Epic Laws of Folk Narrative," in Alan Dundes (ed.), The Study of Folklore. Englewood Cliffs: Prentice-Hall. 1965. pp. 129-141. Trans. by J.P. Steager. [Originally published in 1909].

Pirkey de-Rabbi Eli'ezer-Pirkey de-Rabbi Eli'ezer. Shmuel b. Rabbi Eliezer Lurya, ed. Jerusalem: 1970.

Qurțubī, Tafsīr-Qurțubī (al-), Muḥammad bin Aḥmad bin Abū Bakr bin Faraḥ, Abū 'Abdallāh (d. 671 A.H./1273 C.E.). Tafsìr al-Qurțubī. Aḥmad 'Abd al-'Alīm al-Bardūnī, ed. Cairo: Dār al-Sha`b, 1372 A.H. [1952 C.E.].

Radtke, B., John O'Kane. The Concept of Sainthood in Early Islamic Mysticism: Two Works by al-Hakim al-Tirmidhi. Richmond, U.K.: Curzon Press, 1996.

Reuven Firestone, Journeys in Holy Lands-Firestone, Reuven. Journeys in Holy Lands: The Evolution of the Abraham-Ishamel Legends in Islamic Exegesis. Albany: State University of New York Presss, 1990.

Schwili-Schwili, Jefet. Jefet Schwili erzahlt: Hundertneunundsechzig jemenitische Volkserzahlungen aufgezeichnet in Israel, 1957-196o. Hrsg. von Dov Noy. Supplement Serie zu Fabula: Zeitschrift fur Erzahlforschung, Reihe A, Texte 4. Berlin: W. de Gruyter, 1963.

Shaybānī, Al-Āhāè wal-Mathān̄-Shaybānī, Ibn Abī 'Āṣim, Aḥmad bin 'Amrū

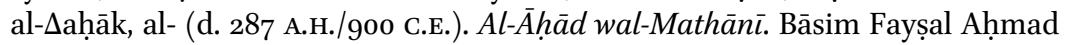
al-Jawābira, ed. Riyad: Dār al-Rāya, 1991.

Stevens, Ariadne's clue-Stevens, Ariadne's Clue-Stevens, Anthony. Ariadne's Clue: A Guide to the Symbols of Humankind. Princeton: Princeton University Press, 1998.

Suyūṭì, al-Durral-Manthūr —Suyūṭi (al-), 'Abd al-Raḥmān bin Abī Bakr Jalāl al-Dīn (d. 910 A.H./1505 C.E.). Al-Durr al-Manthūr fil-Tafsìr al-Ma'thūr. Beirut: Dār alFikr, 1993 .

This Week in Palestine-Story of the Week [online]. Jerusalem Media \& Communication Centre (JMCC), February 2000 [cited November 06 2010]. Available from: $<$ http://thisweekinpalestine.com/details.php?id=703\&ed=63\&edid=63>. 
Tirmidhī, Sunan —Tirmidhī (al-), Muḥammad bin 'Isā Abū 'Isā al-Sulamī (d. 279 A.H./ 892 C.E.). Al-Jāmi al-Ṣaḥ̄ḥ Sunan al-Tirmidhī. Aḥmad Muḥammad Shākir et al., eds. Beirut: Dār Ihyā'’ al-Turāth al-'Arabī, n.d.

Urbach, Sages - Urbach, Ephraim E. The Sages: Their Concepts and Beliefs. Publications of the Perry Foundation in the Hebrew University of Jerusalem. Jerusalem: The Magnes Press, 1983 [Hebrew].

van Ess, J. “Qadariyya.” $E I^{2}$. Vol. VI, pp. 368-372.

Wāsi'ī, Ta'rīkh al-Yaman-Wāsi'ī, 'Abd al-Wāsi' bin Yahyā. Ta’rīkh al-Yaman. Cairo: Al-Mațba'a al-Salafiyya wa-Maktabatihā, 1346 A.H.

Zohar-Sefer ha-Zohar. New York: Yeshivat Kol Yehuda, 2004.

Ṭabarānī, Al-Mu jam al-Kabīr - Ṭabarānī (al-), Abū al-Qāsim Sulaymān bin Aḥmad (d. 360 A.H./971 C.E.). Al-Mu jam al-Kabìr. Hamdī bin 'Abd al-Ḥamīd al-Salafì, ed. Mosul: Maktabat al-'Ulūm wal-Hakam, 1983.

—, Al-Mu'jam al-Ṣaghīr-Ṭabarānī (al-), Abū al-Qāsim Sulaymān bin Aḥmad (d. 360 A.H./971 C.E.). Al-Mujam al-Ṣaghïr lil-Ṭabarānī. 'Abd al-Raḥmān Muḥammad 'Uthmān, ed. Medina: Al-Maktaba al-Salafiyya, 1968.

Tabarī, Tafsīr - Tabarī, Muhammad bin Jarīr Abū Ja'far (d. 310 A.H./923 C.E.). Tafsìr al-Ṭabarī. Beirut: Dār al-Fikr, 1405 A.H. [1984 C.E.].

—, Ta'rīkh — Ṭabarī, Muhammad bin Jarīr Abū Ja far (d. 310 A.H./923 C.E.). Ta'rīkh al-Tabarī. Beirut: Dār al-Kutub al-'Ilmiyya, 1407 A.H. [1986 C.E.]. 